\title{
OBITUARY
}

\section{JOSEPH BERTRAND MCAREVEY}

IN the death of Joseph Bertrand McArevey on February 24, 1951, at the age of 54 . Irish Ophthalmology has suffered a severe loss, and those of us who were most intimate with him mourn a staunch friend.

He became a member of the Honorary Staff of the Royal Victoria Eye and Ear Hospital, Dublin, in 1924, and gave early promise of what he was to become, an operator of outstanding ability. His absorbing interest in operative work is evidenced by his papers and reports of cases given at the meetings of the Irish Ophthalmological Society, and duly published in the Transactions.

In 1944, the Council of the Royal College of Surgeons Ireland invited him to deliver the Montgomery Lecture. His paper, "The Social and Medical Problems of Phlyctenular Disease in Dublin ", provided us with a clear-cut analysis of relevant facts, and afforded him the opportunity to focus attention on the low standard of living amongst the poor of Dublin. It may well have been this opportunity which determined his choice of subject.

His stimulating presence will be sadly missed by none more than by his colleagues on the Prevention of Blindness Committee of the National Council for the Blind in Ireland.

He had wide interests. He acquired an extensive knowledge of old furniture, Waterford glass, and old Irish silver, but he was at heart a rambler, and never aspired to the absorption of the collector. He was a single-figure golfer, and a keen shot, but what he loved best were long tramps in the country, not for a destination, but for the joys of the open road.

The keystone of his character was courage. At the age of 18 , then a medical student in the National University of Ireland, he joined the Army; in 1915 he was granted a commission in the Royal Irish Rifles, and he won the M.C. in 1917.

He was a courageous operator, keenly alive to new developments, and never daunted by technical difficulties. When he recently introduced to Dublin the operation of trabeculotomy for buphthalmos, colleagues from all over the country sent him such cases as came their way. There could be no higher tribute to his judgment and skill.

His courage never shone brighter than when, at the height of his powers, he realized that the end was near. 